\title{
The Use of Android-Based Dictionary Game for Arabic Vocabulary Learning in Elementary School
}

\author{
$1^{\text {st }}$ Abdul Mutholib ${ }^{1}, 2^{\text {nd }}$ Ma'rifatul Munjiah $^{2}, 3^{\text {rd }}$ Siti Muflichah $^{3}$ \\ \{albarbasiy200274@gmail.com ${ }^{1}$, munjiah@bsa.uin-malang.ac.id ${ }^{2}$, movely-mufli@gmail.com ${ }^{3}$ \} \\ IAIN Kudus, Kudus ${ }^{1}$, UIN Maulana Malik Ibrahim, Malang Indonesia ${ }^{2}$, Queensland University, St \\ Lucia QLD 4072 Australia $^{3}$
}

\begin{abstract}
In the field of teaching and learning of the Arabic language, the dictionary has a special role as the teaching media that are used by teachers to enrich the vocabulary of the students easily and fast. Vocabulary has a significant impact on the adequacy of language development. Therefore, a lot of educational strategies has developed in order to raise students' motivation toward learning the Arabic language, especially in order to raise their interest and their orientation in keeping vocabulary, practicing it in speaking, reading and writing. The android-based dictionary game is the exciting strategy to train students to be master through the competition to define the meanings of difficult vocabulary quickly and accurately. This article presents android-based dictionary game in Arabic vocabulary learning, and also explains a strategy model for integrating android and media into students' vocabulary learning experience in the classroom.
\end{abstract}

Keywords: Arabic vocabulary learning; dictionary game; android; internet, elementary school.

\section{Introduction}

Vocabulary is one of the important elements of the Arabic language that must be mastered by learners to sustain their ability in listening, speaking, reading and writing. "Vocabulary is also an area where teachers are asking for guidance on instructional approaches, strategies, and materials" ${ }^{[1]}$. The minimum number of vocabularies that must be mastered by students for mastering Arabic language skills, are around 750-1000 words, provided that they have been given mastery of structures and of using dictionaries ${ }^{[2]}$. For that reason, "vocabulary should be considered in a balanced way compared to other language elements. Because, vocabulary has a large role in the development of students' language skills mastery" [3]. Thus, with sufficient vocabulary knowledge, students are able to communicate with others well, and express their opinions and feelings with the language they learn. Therefore, the teacher must do various language exercises for learners to practice vocabulary skills and understand their meaning, memorize it, and use it properly and correctly.

Various learning strategies have been developed by Arabic teachers as the perfect solution for achieving vocabulary learning. Especially, to stimulate learners' motivation in learning Arabic, and stimulate their interest in memorizing vocabulary and using it in speaking, reading and writing. Some of them make use a dictionary that is packaged creatively into a game of language known as a dictionary game. And the android-based language game is a choice of contemporary strategies that attract learners to train them in vocabulary mastery through 
competitive activities in recognizing the meaning of difficult vocabulary quickly and carefully.

Dictionary is not new. Now in the global era, an era that requires the use of foreign languages as a means of communication between individuals, between institutions, and between countries in the world, dictionaries become items that must be owned by each individual. In fact, in an era of information and communication technology (ICT) that is increasingly sophisticated and growing very fast, dictionaries are always hunted and accessed every time. Humans need a translator tool for each of their activities. In fact, in Arabic classes the existence of dictionaries is always needed. Teachers and students need dictionaries that are easy to get and are used to find vocabulary and find meaning in a practical and fast way.

The use of dictionaries as a tool in learning Arabic is common and ordinary. However, not all students are good at using dictionaries, some even find it difficult to find a vocabulary they are looking for. Then, the question arises: is the dictionary being used incomplete? Or the owner of the dictionary who does not know how to use it? Or do they not yet know how to search for a word in the dictionary? Or are they not used to using dictionaries because they don't have a dictionary? Or even, do they prefer to ask friends like "walking dictionary" rather than having to open a dictionary?

In addition, we are confronted with the reality, especially that which occurs in Islamic elementary schools, as stated by Fakhrurrozi, that "in the selection of vocabulary learning materials for children, teachers are usually fixated on available material which is usually in the form of textbooks. It is very lucky, if the teacher can use textbooks that are interesting, systematic and in accordance with the syllabus used in their school. However, from the point of view of children, it is very boring if the material presented by the teacher only comes from a textbook" ${ }^{44]}$.

In fact, in the era of communication and information technology, "the era that impossible to avoid it" ${ }^{[5]}$. Technology has changed the way of students in learning, and even the way of teachers in teaching in the classroom.

Therefore, nowadays, the subject matter needs to be presented creatively, including in the presentation of vocabulary learning materials, among them by utilizing a dictionary designed by teachers creatively with the help of android technology, so it becomes a popular language game application known as android based-dictionary game. With this application, learners are expected to use the dictionary to search for and discover the meaning of vocabulary; and can increase their interest and motivation in learning vocabulary, memorizing it and using it when listening, speaking, reading and writing; and the learners are also expected to learn Arabic happily, competitively, and learn together in order to obtain the best results in learning Arabic.

This paper will discuss the use of android technology in Arabic vocabulary learning in elementary school. The main issues discussed are: how is a dictionary game that uses android app? And how is the use of these android-based dictionary game in learning Arabic vocabulary in elementary school?

\section{Literature Review}

\subsection{Technology and the Challenges of the Age in Education}

The word technology is the most widely used word of our time. The current era is characterized by the explosion of knowledge and technology, the proliferation of communication systems, the increasing use of computers and the expansion of the use of the 
internet, which has made the world an electronic global village. States have begun to feel the growing importance of computer literacy by providing an interactive learning and training environment that attracts the attention of individuals in an age characterized by rapid development and constant change. The employment of information technology and the internet in training and education is one of the most important indicators of the transformation of the society into an information society, as this will contribute to increasing the efficiency and effectiveness of education systems and in the dissemination of information awareness and thus contribute to building the information cadres sought by the societies in the current era. ${ }^{[6]}$

The main reason for using technology in teaching and learning is to gain multiple benefits as follows:

1) Increase the effectiveness of learning and degree of proficiency.

2) Reduce the time the teacher needs to reach the designed goals.

3) Increase the efficiency of teachers in view of the numbers they know without detracting from the quality of education.

4) Reduce cost without affecting the quality of learning.

5) Increase the productivity of the educational process, by freeing the teacher from the routine work, and give him the opportunity to devote to help his students to learn, and planning their activity, and the teaching of basic skills.

6) The establishment of the educational process and its establishment on scientific grounds, to rely on the results of research documented in human learning, and to benefit from the results.

7) Modifying behavior and highlighting new trends.

8) Develop linguistic wealth, help build new concepts sound, clear.

\subsection{Android and Its Use in Education}

Android is a free operating system developed by Google, an operating system for devices that contain touch screens such as smartphones and tablets. Now, "the android system in the electronics market is becoming more and more popular, especially in smartphone market. Because of the open source, some of the development tools are free, so they are plenty of applications generated. This greatly inspired the people use the android system" " ${ }^{[7]}$.

There are three types of android Apps: Native, Web-based and Hybrid. "Many users are interested in using native mobile apps as they can be used even when there is no internet connectivity" ${ }^{[8]}$. Various domains of Android Applications include Entertainment, educational purposes, retail, financial, social, travel, education, healthcare etc.

Some researches indicate that the use of android apps for learning makes it easy, effective and fun [9] [10] [11]. Drawing on these researches, many android applications have been developed for educational objectives, such as horizontal educational expansion, knowledge flow, multiple knowledge vessels, multiple human tools, solving learning problems, facilitating learning and solving problems of excessive pronunciation. Students have started using Apps for educational purposes. "Many Apps are available which provides course material and assignments for practice. Also, students can choose to display information according to their choice." ${ }^{[12]}$ For example, there are many android applications that can solve the problems of Arabic language teaching and learning and can facilitate for Arabic vocabulary learning. Different famous apps for Arabic vocabulary learning include Learn Arabic Vocabulary-6000 words or Learn Arabic Vocabulary Free.

\subsection{Dictionary Game: Its Use in Vocabulary Learning}


In the context of language teaching and learning, the use of the game has become a strategic, exciting and popular place for children. There are many educational benefits offered by games to children" ${ }^{[13]}$.

Drawing on research-based principles of vocabulary learning and multimedia learning, there are many strategies that use game to engage their students in vocabulary learning. The strategies are designed to support the teaching of words and word learning strategies. One of the popular games for vocabulary learning is dictionary game. It is "a collective activity by a team of students, where students build vocabulary, where students compete with each other to define the meanings of difficult words facing them quickly and accurately defined. This game will strengthen the skill of students in the use of the lexicon of the school efficiently, as the use of the lexicon in the detection of the meaning of the vocabulary contributes to the knowledge of the root of the word, as well as to identify the different meanings of the single language, and the contexts in which it usually and how to pronounce correctly" [14].

Al-Bari ${ }^{[15]}$ said that there are six steps in learning vocabulary using the dictionary game, that are:

1) The students are divided into groups or teams of 4-5 students each. Then the teacher gives a diction to each team (or the teacher asks each team to prepare one diction on the previous day), with the diction that is distributed/ prepared is a dictionary that has the same specifications (thickness size and publisher) so that the game runs fairly.

2) The teacher mentions the rules of the game for all teams: each student has to search for a new word in the dictionary individually without the help of a friend of his team.

3) The teacher starts the game by asking the students to read certain sentences contained in the reading, then the teacher determines a word to look for in the dictionary. When the teacher points to a word and designates a student in each team, then each designated student starts competing to find its meaning through the dictionary.

4) Then, one of the team members conveys the definition of the word searched, in addition to specify the mode of pronunciation and the fragment of its pronunciation.

5) The team capable of delivering the definition of the vocabulary searched properly and completely will be the "winning" team and the team entitled to submit the final conclusion report of the discovery of the word.

6) Then the teacher appoints another team to be the first team challenger who has won in the first round, by raising new words that have not been found by the first team, and so on until the word to be searched has been "exhausted" or all definitions are known.

\section{Discussion}

\subsection{How is a dictionary game that uses android app?}

It is clear from the definition of dictionary game that the main elements of the game are goals, order, challenges and dealings. The game usually involves the excitement of the psychological brain or the physical excitement, or sharing them together. The whole game helps the development of practical competencies, and is considered as a means in the exercises, or play an educational role, and works as a demonstrator or psychologically active. Sugiarsih said, that "the game is a way for children to surf the world, from things not even known to things known, from things that are not even to things that can be done to them. It is correct to say that games and their practicality for children have important value and privacy in promoting the development of daily life" [16]. 
In the context of language teaching and learning, the use of the game has become a strategic, exciting and popular place for children. Because the language game is an effective way to abort the spirit of learning and prepare a place for recovery from the dryness of learning. The learning share is represented by learning to play within active learning strategies, in application of educational quality, and in the pursuit of quality educational services. The strategy of learning by playing is an effective educational tool that helps to achieve the goals associated with the curriculum to develop students' ability to communicate and interact with others. The strategy develops the mental, and raises the mind to think, and increase the positive classroom interaction significantly in the transmission of the impact of learning, and give meaning to what the student teaches within the framework of education, combining the benefit and fun.

Despite these benefits, the effectiveness of learning by using game can't be achieved if it is not designed well ${ }^{[17]}$. Mahmud Ismail Shini proposes to choose the game taking into account the following things: (1) educational material, (2) educational objectives, (3) individual differences for students, (4) communication problems in the classroom, (5) psychological conditions among learners in the classroom, (6) design of education process, (7) facilities and devices available in the classroom [18].

Therefore, the android applications have been developed for educational objectives such as horizontal educational expansion, knowledge flow, multiple knowledge vessels, multiple human tools, solving learning problems, facilitating learning and solving problems of excessive pronunciation. There are many android applications can be integrated into Arabic vocabulary learning in the classroom. But, the choosing android apps has to fulfill these criteria: (1) the choose application has created depending on principles of vocabulary learning and multimedia learning, (2) the app has to be suitable for individual differences for students and for the psychological conditions among learners in the classroom, (3) the app has to adapted to vocabulary learning objectives, (4) the app has to be easy to use and can give solution for communication problems in the classroom.

Some android apps have fulfilled these criteria include the following:

1) Learn Arabic Vocabulary-6000 words. This app is created by FunEasyLearn. With this apps, students can learn Arabic for free, learn more than 6000 words trough image illustration, recorded pronunciation, and native translation into 59 languages.

2) Learn Arabic Vocabulary free. This app is designed for rapid Arabic learning of vocabulary and phrases. In this apps, available Flashcard language lessons:

- Most frequent Words in Arabic (Beginner A1, 500 words; Elementary A2, 501-1250 words; Lower Intermediate B1, 1251-2250 words; Upper Intermediate B2, 2251-3500 words; Advanced C1, 3501-5000 words).

- $\quad$ Add your own vocabulary list. If you are taking a course at a school, university or private academy, you can add the words from your textbook and learn them here instead of looking them up in a dictionary.

\subsection{How is the use of the android-based dictionary game in learning Arabic vocabulary in elementary school?}

Arabic vocabulary learning is an important and indispensable part of Arabic language learning process. The objectives of Arabic vocabulary learning are that "not only is the student proficient in pronouncing their voices, and understanding their meaning independently, and learning how to derive them, or just describing them in a correct language structure, but are that the student is able to all this, in addition to something else is to be able to use the appropriate word in the appropriate context. Therefore, the teacher must train students on the 
following things: (1) understanding the meaning of the word, (2) pronunciation, (3) derivation, (4) using word and its meaning in the sentence ${ }^{[19]}$.

In order to achieve these objectives, the teacher must provide his students with some strategies that help them to learn. And he must train them on some strategies and techniques that contribute to the increase of vocabulary. The teacher must apply the basic principles of vocabulary teaching as follows:

(1) Provide adequate opportunities for students to learn the language.

(2) The teacher's diagnosis of more than three thousand words used by the learner.

(3) Direct and direct learning of vocabulary.

(4) Provide adequate opportunities for the expansion of knowledge of words.

(5) Provide the opportunity to increase vocabulary fluency of words known to the emerging.

(6) Individual experimentation and use in multiple language contexts.

(7) Test different dictionaries and choose the easiest for students. [20]

Based on these principles, many educational strategies have been developed to teach vocabulary in order to stimulate students' motivation to learn Arabic, especially to stimulate their interest and tendency to memorize, to practice, and to use vocabulary in conversation, reading and writing. One of the strategies developed is implementing an android-based dictionary game. This game is an exciting strategy to train students for acquiring and controlling vocabulary through competition to define the meanings of difficult vocabulary quickly and accurately. Al-Bari said that there are six steps in learning vocabulary using the dictionary game, that are:

1) The students are divided into groups or teams of 4-5 students each. Then the teacher gives a diction to each team (or the teacher asks each team to prepare one diction on the previous day), with the diction that is distributed/ prepared is a dictionary that has the same specifications (thickness size and publisher) so that the game runs fairly.

2) The teacher mentions the rules of the game for all teams: each student has to search for a new word in the dictionary individually without the help of a friend of his team.

3) The teacher starts the game by asking the students to read certain sentences contained in the reading, then the teacher determines a word to look for in the dictionary. When the teacher points to a word and designates a student in each team, then each designated student starts competing to find its meaning through the dictionary.

4) Then, one of the team members conveys the definition of the word searched, in addition to specify the mode of pronunciation and the fragment of its pronunciation.

5) The team capable of delivering the definition of the vocabulary searched properly and completely will be the "winning" team and the team entitled to submit the final conclusion report of the discovery of the word.

6) Then the teacher appoints another team to be the first team challenger who has won in the first round, by raising new words that have not been found by the first team, and so on until the word to be searched has been "exhausted" or all definitions are known. ${ }^{[13]}$

Actually, the steps of dictionary game can be created and developed by the teachers according to the characteristics of learners, objectives and materials taught. That is, by creating new game rules. Here are some game rules (as an alternative) that can be applied in the dictionary game:

Alternative \#1:

(1) A dictionary game activity is performed in pairs;

(2) Students first write one word (verb / noun) in Arabic, for example "دراسة", then he writes the first letter of a word that the second student must guess, for example "ح"; 
(3) The second student guesses by saying the word according to the first letter written by the first student, e.g. "حصة";

(4) Then, alternatively, the second student writes the first letter of a word to be guessed by the first student; And so on until it reaches the specified number of words.

Alternative \#2:

(1) A dictionary game activity is performed in pairs;

(2) The first student writes one word in Arabic, for example "تعلم"; Then he asked the second student to guess the translation in Indonesian;

(3) The second student guesses by mentioning the translation of the "Arabic word written by the first student";

(4) Then, alternatively, the second student who gets the turn to write a single word in Arabic which should be mentioned in the Indonesian language by the first student; And so on until it reaches the agreed number of words.

Alternative \#3:

(1) A dictionary game activity is performed in pairs;

(2) The first student writes one word in Arabic and the translation at once, for example "تعليم" means "teaching"; Then, he writes the first letter of a word to be guessed by a second student, such as the letter " $\square$;

(3) The second student guesses the word meant by the first student as well as the translation: "مدرس" means "teacher";

(4) Furthermore, the second student who gets the turn to write the first letter of a word to be guessed by the first student, and so on, until it reaches the agreed number of words.

The following is a vocabulary learning model using an android-based dictionary game in elementary school:

- $\quad$ Before use, the teacher must prepare a number of vocabulary cards of direction (e.g., four cards), and prepare a number of dictionaries, and choose an android-based dictionary game available in google play (like: Learn Arabic Vocabulary-6000 words or Learn Arabic Vocabulary Free).

- $\quad$ then, the teacher divides the students into four groups (in each group five members of students), and then the teacher asks each student to run the application;

- The teacher explains the rules of the game that each group should adhere to in this game: "Each student individually works in the search for new vocabulary in the application, and Each student does not assist to other student in his group until finish the individual search for this vocabulary".

- $\quad$ Then, the teacher asks one of the students to be in front of the class to get the card. If the group has finished searching for the vocabulary that asked in the card, another member of that group can proceed to the chapter without waiting for the call to obtain the next card, so until the end of the other card.

Here is an example of the following:

Read this guide in the card, then search for any word in the box using the android apps (Learn Arabic Vocabulary Free)!

Table 1. Example

\begin{tabular}{|c|}
\hline CARD \#1 \\
\hline $\begin{array}{c}\text { This word is started by harf QAF, it's a } \\
\text { tool used by student for writing }\end{array}$ \\
\hline
\end{tabular}




\begin{tabular}{|c|}
\hline CARD \#2 \\
\hline $\begin{array}{c}\text { This word is started by harf SIEN, it's } \\
\text { used by teacher for explaining lesson in } \\
\text { classroom }\end{array}$ \\
\begin{tabular}{|c|}
\hline CARD \#3 \\
\hline $\begin{array}{c}\text { This word is started by harf KHA', it's } \\
\text { used by students for carrying tools of school }\end{array}$ \\
\hline \\
CARD \#4 \\
This word is started by harf THA', it's \\
used by teacher for writing the lesson on the \\
blackboard
\end{tabular}
\end{tabular}

Then, the student returns to his group, and shares with other members, to discuss the vocabulary that suits the guide. Each group must find the appropriate word in the given directory written in the Cards. Each group, which was the fastest in finding all the words correctly, become a winner in this game.

- $\quad$ In the final process, the teacher asks each group to submit their findings to the class. In this process, the teacher performs the entire set and assigns one of them as the winner in this game.

\section{Conclusion}

In closing, the author invites the teachers of Arabic language to use android baseddictionary game that can support active learning. This game has many educational benefits, which increase the effectiveness of Arabic vocabulary learning and degree of proficiency. Many android based-dictionary games have been developed to learn Arabic vocabulary, the teacher must choose one of the appropriate android-based dictionary games that has to fulfill some criteria, and use it for integrating android into his students' vocabulary learning experience. And, for implementing an android-based dictionary game, there is a vocabulary learning model using an android-based dictionary game in elementary school, but the teachers can create the steps of dictionary game according to the characteristics of learners, objectives and materials taught.

Acknowledgements. This paper in conjuction with the 1st Annual International Conference on Language, Literature and Media (AICOLLIM)

\section{References}

[1] Dalton, B. and Grisham, D. L. eVoc Strategies: 10 Ways to Use Technology to Build Vocabulary. The Reading Teacher, 64. 2011. pp 306-317. Doi: 10.1598/RT.64.5.1

[2] Neneng. Pembelajaran Mufradat dalam Pembelajaran Bahasa Arab, retrieved from http://bdkjakarta.kemenag.go.id/index.php?a=artikel\&id =870 at 10 March 2016.

[3] Al-Qahtaniy, Mofareh. The Importance of Vocabulary in Language Learning and How to Be Taught. International Journal of Teaching and Education, Vol. III (3), 2015. pp. 21-34. Doi: 10.20472/TE.2015.3.3.002 
[4] Fakhrurrozi, Aziz, et. all. Pembelajaran Bahasa Arab. Jakarta:Direktorat Jenderal Pendidikan Islam Kemenag RI. 2012.

[5] Nayif, Nayip Abdullah. Al-Ta'lim al-Taqniy wa Tahaddiyatu al-'Ashr. Baghdad: Majalah Kulliyah Baghdad li al-Ulum al-Iqtishadiyah. $22^{\text {nd }}$ Ed. 2009.

[6] Al-Hijri, Ibrahim Abdullah. Al-Ta'lim fi al-Wathaniy al-Arabiy wa al-Tahaddiyat alTeknologiya. Sana'a: Faculty of Science Sana'a University Republic of Yaman. n.d.

[7] Li Ma, Lei Gu, Jin Wang. 2014. Research and Development of Mobile Application for Android Platform. International Journal of Multimedia and Ubiquitous Engineering Vol. 9, No. 4 (2014). pp. 187-198. http://dx.doi.org/10.14257/ijmue.2014.9.4.20

[8] Abhinav Kathuria, Anu Gupta. 2015. Challenges in Android Application Development: A Case Study. IJCSMC, Vol. 4, Issue. 5, May 2015, pg.294-299

[9] Arisanti, Eka Yuli. 2012. "Aplikasi Pembelajaran Bahasa Jerman Level Dasar Berbasis Android” (unpublished). Surabaya: Institut Teknologi Sepuluh November.

[10] Arif Tri Septiawan, Aris Rakhmadi, Ady Purna Kurniawan. 2012. Pengenalan dan Pembelajaran Cara Membaca Al-Quran (Ilmu Tajwid) Berbasis Mobile Android. (Paper Unpublished). Surakarta: UMS Surakarta

[11] Dian Wahyu Putra, A. Prasita Nugroho, Erri Wahyu Puspitarini. 2016. Game Edukasi Berbasis Android sebagai Media Pembelajaran untuk Anak Usia Dini. JIMP - Jurnal Informatika Merdeka Pasuruan Vol.1, No.1 Maret 2016. pp. 46-58

[12] Abhinav Kathuria, Anu Gupta. 2015. Challenges in Android Application Development: A Case Study. IJCSMC, Vol. 4, Issue. 5, May 2015, pg.294-299

[13] Su Kim, Lee. Creative Games for The Language Class. Forum Vol. 33 No.1 January-March 1995.

[14] Al-Bari, Mahir Sya'ban Abdul. Istiratijiatu Ta 'lim Mufradât. Oman: Dar al-Massira. 2010. p. 342.

[15] Al-Bari, Mahir Sya'ban Abdul. Istiratijiatu Ta'lim Mufradât. Oman: Dar al-Massira. 2010.

[16] Sugiarsih, Septia. Permainan Bahasa dalam Pembelajaran Bahasa Indonesia di SD. Makalah Pengabdian Masyarakat di SD Negeri Bayat Klaten. 2010.

[17] Al-Shuwerqi, Muhammad Ali. Al-Al'Ab al-Lughawiyah wa Dauruha fi Tanmiyati Maharat al-Lughah al- 'Arabiyah. Oman: Maktabah al-Thalabah al-Jami'iyyah. N.d.

[18] Shiniy, Mahmud Ismail, et.all. Dalil al-Mu'allim ila istihdami al-Shuwar wa al-Bithoqot fi Ta'lim al- 'Arabiyah. Riyad: Maktabah Tarbiyah Riyad. 1991. 